\title{
Global Deluge, Theophany and the Ut-napištim-Noah-Oppehnaboon Connection
}

\author{
Aaron Valdis Gauss \\ Graduate Institute of Children's Literature \& Department of English \\ National Taitung University No.369, Sec. 2, University Road, Taitung City, Taitung County 95092, \\ Taiwan (R.O.C.)
}

\begin{abstract}
It is a long established fact that stories of a global flood permeate oral traditions and mythologies in every corner of the Earth. Of these global deluge epics, the most well-known are those of the biblical Noah and of Ut-napištim recorded in the Sumerian Epic of Gilgamesh, both of which were recorded in antiquity. As such, any comparisons of flood texts can reasonably begin with a consideration of the similarities and differences of a flood myth with those of Noah and of Ut-napištim, and they often are.Taiwan's Saisiyat tribal myth of Oppehnaboon is remarkably similar to the accounts of both Ut-napištim and Noah. The current study examines correlations in character background, communication with and manifestation of transcendental messengers (theophany), stated causes for the deluge, post-flood commandments and other parallels which are featured in the accounts. This study sheds light on one of the lesser known Saisiyat tribe's myths of Oppehnaboon and serves as a first step to a more in depth investigation of Formosan global deluge myths.
\end{abstract}

Keywords: Formosan mythography; Saisiyat; Theophany; Flood myth; Oppehnaboon; Ut-napištim; Noah

DOI: $10.7176 / \mathrm{JLLL} / 83-01$

Publication date: November $30^{\text {th }} 2021$

\section{Introduction}

"The myths and legends of Taiwan's indigenous peoples...stand as a gateway to our understanding of indigenous culture and history" (Russell xxix). However, shockingly few English language studies have explored the rich and diverse corpus of Formosan mythological texts. This significant knowledge gap must be bridged so that the ancient myths of Taiwan's aboriginal tribes can take their place in the pantheon of global oral literature. As such, this paper principally explores and investigates the Taiwanese Saisiyat tribe's deluge myth as retold by Winkler and compares its most salient elements with those found in other prominent ancient global deluge texts.

The oral literature which is known as "myths and legends" reflects the experiences and histories of preliterate peoples. The etymological transliteration of myth comes from the Greek muthos "story" and the suffix -logy meaning "knowledge" (Wilkinson 12). Ho points out that Formosan stories regarding the ahistorical era are categorized as myths. For the purposes of the present study "Myths... are considered to be truthful accounts of what happened in the remote past. They are accepted on faith (and) they are taught to be believed" (Bascom 4). Bascom's definition of "myth" is foundational because it represents a meaning closer to that held by the tellers of the myths and the context in which they are shared. Indigenous performing artist Thomas Riccio echoed Bascom's sentiment stating that "myth is central to what you are, what you value, how you see yourself, and how you exist in the world" (Russell 100).

Stories of the great deluge permeate the oral traditions and mythologies in all four corners of the Earth. Australia, South America, North America, Europe, Asia, Africa and of course Austronesia are home to thousands of adaptations of a global deluge myth which is backed up by geological and archeological evidence. With regard to Taiwan, over a dozen terrestrial archeological sites have been documented as bearing cetacean fossil records at elevations of hundreds of meters above sea level (Tsai 119). Were these ancient fossils deposited at high elevations during a flood?

Morris documents over two hundred global flood legends. Gish et al. discuss uncovering at least two hundred and seventy global inundation myths. Others, such as Schoch estimate that there may be as many as five hundred global flood myths. Dang Nghiem Van documents over three hundred flood myths originating solely in Vietnam. My research on Formosan mythology has revealed over two hundred adaptions of dozens of Formosan great deluge myths. I propose that the existence of thousands of adaptations of global flood legends around the world will be documented as more researchers follow the examples of mythologists like Dang Nghiem Van and conduct intensive region specific studies. Regardless of the number of flood myths in existence, the pan cultural nature of global flood myths is significant historically, culturally, linguistically and religiously.

\section{Literature Review of Global Flood Myths}

Minimally, hundreds of core narrative flood legends exist around the world with thousands of adaptions. These myths are told by different peoples, in different places, in different languages and vary greatly in their details. The Mayan flood myth dates the event to $3113 \mathrm{BC}$. However, many other myths are undated, particularly those 
that survived until recently exclusively via oral tradition.

Over two hundred adaptations of the Formosan flood myths have been catalogued in the Formosan Deluge Mythography by the author. The first body of Formosan myths was primarily recorded by Japanese researchers Erin Asai, Naoyoshi Ogawa, Ino Kanori, Shinji Ishii and Kono Kiroku around the turn of the $20^{\text {th }}$ century. Later, in the middle of the century, researchers Toichi Mabuchi and Ting-Jui Ho continued in the work and translated much of the previous works from Japanese into English. Around the turn of the $21^{\text {st }}$ century researchers Chungchen Pu, Robin Winkler, Robert Early and John Whitehorn published impressive collections of Formosan myths and in all of these publications, deluge myths are chronicled. A number of other researchers contributed to the recordation of Formosan mythic texts as well.

Taiwan's first Roman Catholic Bishop of aboriginal background, Dangalo Kingzi (also known as Tseng Chien-tsi) recorded the legend of the flood as told by the Shisheng Phratry of the Puyuma in 1998. The Puyuma myth states that during the flood, "the land was engulfed, most of the life on it drowns. Even the sun and moon in the sky perished" (Tseng "Puyuma" 17). Only five siblings survive the deluge. One of them becomes the sun, one of them becomes the moon and the other three siblings are the only three humans spared. This mythological account of siblings repopulating the earth is a topic that will be explored more fully later.

Kingzi's telling represents just one of six core Puyuma flood myths. A different myth asserts that Taiwan emerges from the sea for the first time after the flood. Another Puyuma myth says that five siblings survive, two of whom become the sun and the moon (Cauquelin 234). In contrast, a third Puyuma myth says that the two survivors are not siblings and didn't meet until after the flood (Tian "Puyuma" 91). The fourth Puyuma myth says a couple floats on a boat to Orchid Island during a flood and then they return to Taitung which is the closest area of Taiwan's main island (Tian "Puyuma" 93). The fifth myth states that a single survivor plants bamboo from which the protoplasts burst forth (Cauquelin 28). Finally, the sixth core myth declares that a man and woman survive and have sons; mother-son incest is implied (Puyuma, A store of Myths). In some cases the survivors endure the deluge by floating on a bamboo raft, in other cases a mortar and in some cases they survive by grasping onto vegetation as the flood encircled them.

The Yorba people of western Africa tell the myth of Obatala who, using a gold chain, climbs down to earth from heaven with a shell full of sand, a hen, a cat and a seed (Hoena 18). Dropping the sand first, the hen which is dropped later scratches up the sand and everywhere that the sand scatters, land forms. The seed is planted and vegetation begins to grow. The cat is employed as the foundation of life and with it people and other animals are created. However, Olakun, ruler of the earth becomes angry because she hasn't given Obatala permission to create anything in her domain. In a fit of rage, she floods the earth and only a few people survive; mankind calls on their creator god Obatala to rescue them which he does (Hoena 22).

The Aztec people of Central and South America told a myth about a man named Tapi. Tapi is instructed by the creator god to make a boat and put his wife and a pair of every kind of animal in it. The other people tease Tapi and make fun of him for believing that a flood is coming (Fackrell 5). But, sure enough, the flood comes and the rest of humanity and all life on earth die. Only Tapi, his wife and some animals on his boat escape death (Fackrell 6).

These myths are a mere sample of the types of oral histories told around the world with regard to a global inundation. For a more robust corpus of two hundred and sixty-seven global flood myths, see Flood Stories from Around the World by Mark Isaak. Mainstream science recognizes that the earth has undergone five distinct ice ages and subsequent global warming periods (Groeneveld). As such, it is widely accepted among scientists that the earth has experienced one or perhaps many worldwide flooding events. There are even researchers who propose that the global flood was the result of an astronomical event in 2807 BC (Carney). Regardless of specific dates, locations or accounts, it is widely accepted that thousands of years ago there was a global mass extinction event which was, at least in part, perpetuated by a flood.

\subsection{Purpose of the Study}

Of all global flood myths, the most well-known are those of the biblical Noah and the Sumerian Ut-napištim recorded in the Epic of Gilgamesh (Carney, Ham and Hodge and Zhong). As such, any comparisons of flood narratives can reasonably be started by considering similarities and differences with these two. The purpose of the current study is to investigate character background, communication and manifestation of a messenger, stated causes for the deluge, post-flood commandments and many other parallels which are featured in the accounts of Oppehnaboon, Noah and Ut-napištim. The documentation of these parallels establishes that the Saisiyat myth about Oppehnaboon shares a number of similarities to the biblical story of Noah and the Samarian account of Utnapištim or "the chosen ones".

\subsubsection{Accounts of Noah}

The story of Noah is uniquely robust in detail because it is richly documented in a number of sources. Noah is born around $2900 \mathrm{BC}$ and the flood occurs around $2300 \mathrm{BC}$ when Noah is six hundred years old. Genesis 6.3 
indicates that 120 years transpire between the time when God tells Noah to build the ark and the time that the deluge actually manifests. Therefore, Noah may be about 480 years old when he receives God's instructions first hand.

According to the apocryphal book of Enoch in Chapter 106, Noah is born in the eighth generation after Adam in the line of Seth. Of Noah's genealogy, we also know that he is the great, great, grandson of Jared, whose name means "descending" because he is born at the time that the Watchers descend from heaven, take human wives and beget the giants (King James Version, Gen. 6). Noah is the great grandson of Enoch, who is the first prophet and man who is raptured. "And Enoch walked with God: and he was not; for God took him" (Gen. 5.24). Noah is the grandson of Methuselah who, living nine hundred and sixty-nine years is the longest living man ever recorded. Finally, we know that Noah is the son of Lamech.

Noah's one hundred and eighty-two year old father Lamech is greatly vexed by the birth of Noah because Noah's "body was white as snow and red as the blooming of a rose, and the hair of his head and his long locks were white as wool and his eyes beautiful. And when he opened his eyes, he lighted up the whole house like the sun, and the whole house was very bright. And thereupon he arose in the hands of the midwife, opened his mouth, and conversed with the Lord of righteousness" (R.H. Charles 1917. The Book of Enoch. 106. 2-3).

Lamech suspects that Noah is not his son and instead suspects that baby Noah is a son of the Watchers, a nephilim telling his father Methuselah "And it seems to me that he is not sprung from me but from the angels, and I fear that in his days a wonder may be wrought on the earth" (Enoch. 106.6).

In response, Methuselah seeks out his father Enoch at the end of the earth who informs Methuselah that Noah's birth is a sign of the flood which is to come six hundred years later. "Yea, there shall come a great destruction over the whole earth, and there shall be a deluge and a great destruction for one year. And this son who has been born unto you (Noah) shall be left on the earth, and his three children shall be saved with him when all mankind that are on the earth shall die, he and his sons shall be saved" (Enoch. 106.15-17).

These prophecies reveal the extraordinary purpose for which Noah is born. Moreover, the oral transmission of prophecy in the accounts of Noah is similar to the way in which Gilgamesh learns about Ut-napištim's flood story which is recorded in the Epic of Gilgamesh. In the case of Gilgamesh, the gods tell Prince Ea, who tells Utnapištim, who in turn tells Gilgamesh the account of the inundation.

Noah is the last man on earth who has found favor in God's sight because he is genetically and morally pure. Noah is not a human-angel hybrid child of the Watchers, called a nephilim. These nephilim/giants enslave mankind and when men can no longer sustain them, they eat the men. "And the giants began to kill men and to devour them. And they began to sin against the birds and the beasts and the creeping things and the fish, and to devour one another's flesh. And they drank the blood. Then the earth brought accusation against the lawless ones" (Enoch. 7).

God responds to the evil works of the morally and genetically corrupt nephilim in a couple of ways. First, God judges the giants and "sent His sword into their midst that they should slay their neighbors, and they began to slay each other till they all fell by the sword and were destroyed from the earth" (R.H. Charles 1917. The Book of Jubilees. 5.1-20). Second, after forcing the Watchers to witness the death of their nephilim offspring, God casts them into a pit to await judgment day. Third, God destroys the Earth with a flood killing everyone and everything terrestrial that isn't on the ark.

Apocryphal records confirm that God's prophetic warning comes again to Noah one hundred and twenty years before the deluge. In His injunction, God takes a position similar to the one He takes in the Book of Jonah by instructing mankind to repent, hoping that they would reform themselves. "And the Lord granted them (mankind) a period of one hundred and twenty years, saying, If they will return, then will God repent of the evil, so as not to destroy the earth" (J.H. Parry \& Company 1887. The Book of Jasher, 5.11). In the Biblical Book of Jonah, the people of Nineveh are given forty days to repent after which "God saw their works, that they turned from their evil way; and God relented from the disaster that He had said He would bring upon them, and He did not do it" (King James Version, The Book of Jonah. 3.10).

Genesis describes Noah as "a just man, perfect in his generations" and that it is because of this that he is selected by God to survive the deluge. Noah's obedience to God and his aversion to the wickedness and corruption of the giants makes Noah the only viable candidate for God. "The earth also was corrupt before God, and the earth was filled with violence. So God looked upon the earth, and indeed it was corrupt for all flesh had corrupted their way on the earth" (Gen. 6.11-12). Noah is part of a long line of highly respected leaders and his birth is considered highly prophetic.

Noah must overcome temptation so compellingly potent that Noah is the last man on earth who has not succumb to it. The second book of the Enoch explains how the Watchers teach antediluvian men the manufacture of weapons of war, the performance of metallurgy, the use of makeup and accessories, sorcery and magic, the reading the signs of lightening, the signs of the stars and shooting stars, the signs of the earth, sun and moon and that the result of this wisdom is global conflict. "And as for all those who corrupted their ways and their thoughts before the flood, no man's person was accepted save that of Noah alone; for his person was 
accepted in behalf of his sons, whom (God) saved from the waters of the flood on his account; for his heart was righteous in all his ways, according as it was commanded regarding him, and he had not departed from aught that was ordained for him" (Jubilees, 5.19).

The knowledge of the Watchers is so evil that when Noah's great grandson Kainam in the line of Shem found the ancient wisdom in the postdiluvian world it causes him to sin greatly. "And he (Kainam) found a writing which the ancestors engraved on stone. And he read what was in it. And he transcribed it. And he sinned because of what was in it, since there was in it the teachings of the Watchers by which they used to observe the omens of the sun and moon and stars within all the signs of heaven. And he copied it down, but he did not tell about it because he feared to tell Noah about it lest he be angry with him because of it" (Jubilees. 8.3-4).

With regard to the countenance of God and the mechanism by which God enters discourse with Noah, the books of Genesis, Jasher and Jubilees say very little. They say simply that "the Lord said" and "the Lord spoke." The books of Ezekiel and Daniel however offer reference to theophany of the God of Noah. God is characterized as being "the color of amber with the appearance of fire all around within it; and from the appearance of His waist and downward I saw, as it were, the appearance of fire with brightness all around. Like the appearance of a rainbow in a cloud on a rainy day, so was the appearance of the brightness all around it. This was the appearance of the likeness of the glory of the Lord" (King James Version, Ezekiel 1.27-28). God is also described as wearing a "garment was white as snow" with hair "like the pure wool" (King James Version, The Book of Daniel. 7.9)." These accounts offer a great deal of detail and could be summarized much in the manner ascribed to god in the Saisiyat myth which illustrates god as "an old man with white hair."

\subsubsection{Accounts of Ut-napištim}

Cuneiform tablets of the Epic of Gilgamesh were rediscovered in 1849 in the ancient Assyrian Royal Library of Ashurbanipal. A separate tablet, the Kings' List, provides a complete chronology of all the antediluvian and postdiluvian kings of ancient Sumer. The King's List confirms that Gilgamesh was a king who reigned around 2700 BC. The King's List also specifies that the first postdiluvian King was Jushur and that he began his rein in $3,100 \mathrm{BC}$ which provides a timeline for dating the great flood.

The Epic of Gilgamesh chronicles King Gilgamesh's quest in the search for eternal life and his meeting with the only man who has ever obtained eternal life, Ut-napištim. Ut-napištim, which means "long life", is also called "The Faraway." Ut-napištim and his wife are born mortal. After surviving the flood however, the god Enlil bestows eternal life upon both of them. Enlil subsequently takes them far away to live for eternity in solitude at the Mouth of the Rivers. Enlil makes the couple immortal but removes them from mankind so that they cannot hold dominion over others.

After finding Ut-napištim at the Mouth of the Rivers, Gilgamesh petitions Ut-napištim saying "how is it that you stand in the Assembly of the Gods, and have found (eternal) life?" (R. Campbell Thompson 1928. The Epic of Gilgamesh 11.7). In Ut-napištim's reply, he reveals the secret history of the earth and how "the hearts of the Great Gods moved them to inflict the flood" (Gilgamesh 11.14).

It is important to consider for a moment the context of the timeline Ut-napištim references. By the time Gilgamesh meets with Ut-napištim and this account is related to him, hundreds of years have passed since the great flood. King Gilgamesh of Uruk was a contemporary of King Aga of Kish who was the $22^{\text {nd }}$ king of Kish after the first postdiluvian king Jushur $(2900-2700$ BC).

Ut-napištim recites his account of how Prince Ea, also a god, warned Ut-napištim that the gods had resolved to destroy the earth because of the unbearable noise created by men. Prince Ea had instructed him to "Tear down the house and build a boat! Abandon wealth and seek living beings!...Make (the seed of) all living beings go up into the boat" (Gilgamesh 11.23-26). Ut-napištim explains how he successfully enlisted carpenters, workmen, children to carry the pitch, and others in the antediluvian world to work with him to build the boat according to very specific measurements given by Prince Ea. Eventually, Ut-napištim recalls how he loaded gold, silver, living beings, beast and animals of the field, craftsmen and all his kith and kin onto the boat just in time before the "the flood came, overwhelming the people like an attack" (Gilgamesh 11.110).

The flood is so terrifying that it frightens the gods who had sent it. Seeing the deluge, the gods scream in fear and hide in their panic. In fact, the gods regret sending the flood; much like God does in the story of Noah.

After the flood is over, Ut-napištim makes a burnt offering to thank the gods for sparing his life and when "the gods smelled the sweet savor, they collected like flies over the sacrifice" (Gilgamesh 11.161). Then, coming together, the gods begin to argue and wonder how it is possible that any people could have survived the flood. When the god Enlil accuses Prince Ea of warning Ut-napištim, Ea admits that he had appeared in a dream to Utnapištim to warn him of the ensuing flood.

Unlike the detail rich accounts of Noah, the Epic of Gilgamesh provides scant clues about Ut-napištim's age or Social Status at the time that Prince Ea commanded him to build a boat. However, upon having been commanded to build the boat, Ut-napištim responds "My lord, this is the command which you have uttered I will heed and will do it. But what shall I answer the city, the populace, and the Elders?" (Gilgamesh 11.36). This 
reply illustrates that Ut-napištim cares foremost about his fellow man, hopes to save humanity and that he is completely obedient to god.

Moreover, the account provided by Ut-napištim is lacking in explicit details regarding the countenance of god and method of theophany; nonetheless, there are some clues. "Gilgamesh spoke to Ut-napištim, the Faraway: 'I have been looking at you, but your appearance is not strange - you are like me! You yourself are not different you are like me!"' (Gilgamesh 11.1-4). This account implies that Gilgamesh expected the immortal Ut-napištim to look somehow un-human. Also, Ut-napištim describes the acts of the gods saying that "The god of destruction, Erragal pulled out the mooring poles, forth went the war god, Ninurta and made the dikes overflow. The gods lifted up the torches, setting the land ablaze with their flare. Stunned shock over Adad's deeds overtook the heavens, and turned to blackness all that had been light. He shattered the land like a raging bull, broke it into pieces like a pot" (Gilgamesh 11.101-107). However, despite these vivid descriptions of the acts of the gods, physical descriptions of them as they manifest themselves to Ut-napištim are unfortunately not included.

\subsubsection{Accounts of Oppehnaboon}

The ancestral languages of Taiwan's aboriginal tribes are linguistically Formosan. However, while the myths are linguistically Formosan, the people ethnographically self-identify as "Taiwanese aboriginals" or Taiwan yuan zhu min (臺灣原住民). The flood myth at issue concerns Oppehnaboon of the Saisiyat tribe.

The traditional living area of the Saisiyat covers portions of Taiwan's north western Miaoli and Hsinchu counties. Of Taiwan's 16 officially recognized tribes, the Saisiyat has the $10^{\text {th }}$ largest population with about 6,730 souls according to the 2020 census published by the Council for Indigenous Peoples. Unfortunately, only an estimated 1,000 people still speak the Saisiyat language with any fluency (Elizabeth Zeitoun, email message to author, July 18, 2021).

Like all of Taiwan's tribes, the Saisiyat were traditionally polytheistic. However, the Saisiyat revere Oppehnaboon foremost because, according to oral tradition, the ethnonym "Saisiyat" was bestowed upon the people by the god Oppehnaboon (Digital Museum) after the flood.

Oppehnaboon (also spelled Otspoehobong, Opohnabolon and Oepoeh) is a central character in many versions of the Saisiyat inundation account. In 1908 Yi Fang recorded the Saisiyat flood myth which includes two survivors descending their mountain refuge in order to dismember corpses which later became children (Chen and Cao 294). In 1917 Shinzo Yasuhara was one of the first chroniclers who related the tale of Oppehnaboon by name. On the character of Oppehnaboon, Yasuhara noted "not sure who he is, he should be a god" (Chen and Cao 296). In Tsuchida's 1964 field study with an elderly Saisiyat couple, Oppehnaboon was labeled "a genie" (44). Ninety-nine years later, in Winkler's 2016 version, Oppehnaboon is described as a man who becomes the spirit of Dabajian Mountain. In some versions of the myth Oppehnaboon is described as being the actual mountain $(P u$ 284), in other adaptions Oppehnaboon is a mortal man who remains a man (Z. Feng) and yet in other versions, Oppehnaboon is specifically described as a god ( $P u$ 77).

Winkler's Taiwan Indigene, characterizes Oppehnaboon as an ordinary man who is visited in a dream by a god who appears as an old man with white hair. As with Noah and Ut-napištim, Oppehnaboon learns through theophany that a deluge is to soon consume the Earth, and that everyone must promptly build boats or face certain death by drowning. Oppehnaboon heeds the warning of the old man with white hair and fabricates a boat. Unfortunately however, none of his fellow villagers follow suit. Subsequently as the rain begins to fall, Oppehnaboon is visited in a second dream and told to abandon his boat and to try to save his people by moving them to a higher elevation. Oppehnaboon does his best to guide his people to safety but the entire Earth is quickly consumed by the deluge and Oppehnaboon manages to save only his sister, Mayanaboon. After the flood, the god manifests to Oppehnaboon a third time in a dream and instructs him to marry his sister in order to save the human race. Later, Mayanaboon gives birth to a child and they promptly chop up the baby into pieces which transform into people who later populate the earth.

Unlike the explicit accounts of Ut-napištim and Noah, the Saisiyat flood myth, as told by Winkler, omits the impetus for the deluge. However, there is one other Saisiyat flood myth in the Formosan Deluge Mythology which provides clues. In Huzisaki's 1938 documentation, it is noted that the flood comes at a time of "great overpopulation on the earth" (Covell 45). Indeed, this also bears a similarity to the Ut-napištim and Noachian accounts.

Incest in the immediately postdiluvian world is a common theme in many deluge myths. Of all the flood myths from the sixteen officially recognized Taiwanese tribes, only the Bunun, Hla'alua, Kanakanavu, Seediq and Truku myths make no mention of incest and the flood myths of the other tribes incorporate incest as a central theme. Furthermore, in addition to being a theme in the Saisiyat myth, the motif of being specifically instructed by a god to marry a sibling in the aftermath of the great flood is additionally found only in Amis and Puyuma deluge myths. For the remaining nine tribes, procreation arises out of necessity or out of a sister's lust for her brother.

The motif of killing and dismembering one's own infant children and using magic to turn their 
dismembered corpse into complete living people is integral to the Saisiyat and Pazeh flood myths. For the Formosan speaking tribes the act of killing one's own children and dismembering their corpses was not always regarded as taboo. Just as approximately 50 million babies are killed in their mother's wombs across the world in 2021 according to the WHO, in some cases infanticide is considered morally required. The Saisiyat believed that "bringing up of twins, bastards or deformed children (was) abhorred, because it (would) bring misfortunes to the family" (Baudhuin 530). Likewise, the neighboring Atayal believed that "bringing up of a bastards, twins, a deformed or mutilated child is abhorred" (Baudhuin 520). In 1885 MacKay wrote that the practice of "immediately destroying" babies was common in poor families in Taiwan, if a baby should be born deformed or born female and that "the sooner the unwelcome baby girl is sacrificed the better" (298).

Moreover, dismemberment of a corpse was not relegated to myth only. Historical records indicate that the dismemberment of live victims, also known as vivisection, resulting in death was employed as a form of punishment in Formosa among the aboriginals as late as the 1880s. MacKay describes how an aboriginal man suspected of murder was dismembered and the severed members of his body were placed in his mouth and he left to bleed to death in the sun by the "pe-po-hoan" people (MacKay 207). Of the six Dominicans who had previously arrived in Formosa in May of 1626, two were dismembered by aboriginals. Father Vaez de Santo Domingo had one arm cut off in addition to being decapitated after being shot to death with multiple arrows. In 1636, Father Luis Muro was found headless and without hands or feet after a 12 day search produced only his arrow riddled corpse (Fernandez 4-5). Incidentally, the death and dismemberment of Father Luis Muro is the direct inverse of the death of the biblical Jezebel (Ahab's widow) who's body was eaten by the dogs but who's head, feet and hands were left (2 Kings, 9.35). In Frederick Coyett's 1675 Neglected Formosa, a detailed account of dismemberment customs is given. "Now if they find anybody either old or young, man or woman, they kill them all, cut off their heads, feet and hands, or take the whole body with them, and cut it in as many pieces as there are men to their party, because every one of them wishes to take a piece of it and display it to his people at home" (De Beauclair "Neglected Formosa" 10).

Oppehnaboon is described a "young man" when he is visited by the vision of the old man with white hair (god). All three chosen ones are men of social prominence who are selected to deliver god's message and ultimately survive the flood.

However, despite Oppehnaboon's prominent social status, Winkler's account records that his people "laugh at" his admonitions and ignore him, which also closely mirrors the account of Noah. Regardless of antediluvian social status, another similarity that all three chosen ones have is that after the flood, they are among the last men on Earth. Despite Oppehnaboon's authority, he expresses reluctance to marry his sister because he remains bound by the cultural taboos of a system he alone is left to enforce and perpetuate. Nevertheless, in his submission to god's command we find a similarity with the story of Noah who marries his cousin Naamah. No information is given on the identity of Ut-napištim's wife. One striking difference however is that Noah marries his cousin and fathers her children prior to the inundation whereas Oppehnaboon marries Mayanaboon after the flood as a last resort to save humanity at the direct order of god. "And Noah was five hundred years old, and Noah begot Shem, Ham, and Japheth" (Gen. 5.32).

Oppehnaboon's obedience to god bears a strong similarity to that of Noah's obedience. In the face of public ridicule and likely public ostracism, the chosen ones nevertheless build the boats that they are commanded to build. Oppehnaboon, Noah and Ut-napištim stop their lives, accept the prophecies and submit to god.

The description of the old man with white hair who visits Oppehnaboon is self-explanatory. Biblical accounts of the appearance of angels and God are analogous to the Saisiyat description of a man with white hair. Revelation 1.14 reveals that God's "head and hair were white like wool, as white as snow, and his eyes were as a flame of fire." Daniel (7.9) describes God stating "the hair of his head like the pure wool." And in support of the fact that every bible verse describing God uses the masculine pronouns "He" and "His" to describe God, Genesis 1.27 reveals that "God created man in His own image" i.e. God's physical appearance is man-like as opposed to woman-like. Likewise, the physical description of Noah reveals that "the hair of his head and his long locks were white as wool and his eyes beautiful. And when he opened his eyes, he lighted up the whole house like the sun, and the whole house was very bright" (Enoch. 106.2).

Noah is described as being albino, not a god, and this association of the color white being associated with divinity is not uncommon. The color white is spiritually significant for many of Taiwan's Austronesian myths. White Mountain (Puzi a hudun), a spiritual place, overlooks the Thao village at Sun Moon Lake. Thao legend also focuses on a white deer that transforms into a woman dressed in white and sacred white stones. Moreover the premise for Thao myth of black and white twins was proven scientifically possible on the cover of National Geographic's April 2018 issue titled "Black and White, These twin sisters make us rethink everything we know about race." The Tao of Orchid Island also believe that a rolling white stone was seen right before the flood. According to the Paiwan origin myth, humans were born from two eggs, one white and one red which were laid by the sun in a house made of white stones on Mount Ka-vulungan.

Biblical descriptions of angels reveal that angels also have bright countenances and, being also made in the 
image of God, look like men. "I lifted up my eyes and looked, and behold, a man clothed in linen, with a belt of fine gold from Uphaz around his waist. His body was like beryl, his face like the appearance of lightning, his eyes like flaming torches, his arms and legs like the gleam of burnished bronze, and the sound of his words like the sound of a multitude" (King James Version, Dan. 10.5-6). There are no biblical or apocryphal descriptions of God or the angels appearing in a feminine form.

The apocryphal book of Jubilees supports Daniel's masculine description of angels stating “And it came to pass when the children of men began to multiply on the face of the earth and daughters were born unto them, that the angels of God saw them on a certain year of this jubilee, that they were beautiful to look upon; and they took themselves wives of all whom they chose, and they bare unto them sons and they were giants" (Jubilees. 5.1). The Watchers did not take husbands; the Watchers took wives after having been seduced by their beauty. The account also states that these fallen angels, also called the Watchers, knew in advance that they would be punished for the great sin of taking human wives and baring giants unto them, but that they did it anyways. Genesis 6.4 announces "There were giants in the earth in those days; and also after that, when the sons of God (Watchers) came in unto the daughters of men, and they bear children to them, the same became mighty men which were of old, men of renown." As heaven is apparently void of female angels, the only females whom the Watcher-class angels had access to are human which further illustrates the absence of female entities in heaven.

On each of the three separate occasions that Oppehnaboon receives instructions from the old man with white hair, Oppehnaboon is visited exclusively in dreams. Furthermore, Oppehnaboon does not engage in dialogue with the god. Rather, Oppehnaboon is a passive recipient of knowledge and instruction whose role is that of an obedient servant. Despite being ordered to start the difficult tasks of preparing for a great storm, building a boat, warning his people of the ensuing catastrophe and eventually marrying his own sister, Oppehnaboon always obeys without protest.

Dreams were a very important aspect of traditional Saisiyat culture and seen as omens and as theophany. Bad dreams on the eve of a head hunting expedition meant that an expedition should be cancelled (Baudhuin 434). Dreams of eating eels, beautiful singing voices emanating from the mountains, dreams of catching dogs or snakes, and dreams of puddles were considered evil omens. Dreams of receiving guns as gifts, hanging on a dog and the death of a sick person were considered good omens (Baudhuin 580).

Like Noah, when Oppehnaboon experiences dream visions of god, he heeds the god's injunction and warns his tribe about the impending deluge. In doing so, he would have gone first to the tribe's elders and later to the public at large to inform them of his vision of god and the commandment which he had received to disseminate the order to build boats. After having been rejected, Oppehnaboon's relationship with his family, friends and community must have suffered significantly. This social pressure and public ridicule does not dissuade him from obeying god.

\section{Discussion on Parallels}

Source materials on ancient myths vary. The present study sources the Saisiyat oral tradition of Oppehnaboon from Taiwan Indigene: Meaning Through Stories (臺灣原住民的神話與傳說套書). That account is used because it is the most readily available in print English version of the Saisiyat myth and because it provides the most details of any Saisiyat myth in the Formosan flood myth corpus.

The story of Ut-napištim is limited to source material found in the Epic of Gilgamesh. Since Ut-napištim was not a king, his name is not recorded on the Sumerian King's List and the only ancient reference to his existence is found on the Tablets 11 and 12 of the Epic of Gilgamesh.

Source materials on Noah by contrast are quite plentiful. For the current study, information about Noah is compiled from three sources. The biblical Book of Genesis and the apocryphal books Jubilees and Enoch all contain substantiating accounts of Noah. The Books of Jubilees and Enoch are part of the Dead Sea Scrolls which were recovered in the decade after the end of World War 2.

Regarding the use of terms, God spelled with a capital $g$ is reserved for the Abrahamic God of the Bible and apocryphal texts such as Enoch and Jubilees while god spelled with a lower case $\mathrm{g}$ is used to refer to any other deity, regardless of origin. Further, since all three of the main characters, Oppehnaboon, Ut-napištim and Noah were specifically chosen to endure the ensuing deluges, they are collectively referred to as the "chosen ones" or "the chosen one" in the case of a singular.

Theophany is "a manifestation of God or a deity" by Webster's New World College Dictionary. Oppehnaboon, Noah and Ut-napištim all experience multiple theophanic visions before and after the great deluge. The account of Oppehnaboon describes the visible manifestation of an unnamed god which, resembling "an old man with white hair," appears to Oppehnaboon on three separate occasions. At the god's first apparition, Oppehnaboon is alerted to the impending deluge and instructed to build a boat. In like manner, both Noah and Ut-napištim are given similar instructions during their theophanic experiences. The second time the god appears to Oppehnaboon to tell him to "give up his boat" and to "lead all of his people to the land above the flood waters." This commandment is unique to the Saisiyat account and is not found in those of Noah and Ut-napištim. 
The third and last time that the god appears to Oppehnaboon, god commands him to marry his own sister in order to have children. "Now there are only you and your sister. In order for your tribe to survive you must marry and have children!" This motif strongly resembles the "Be fruitful and multiply" commandment given to Noah in Genesis 9.1.

An analysis of the method in which god manifests or appears to the chosen ones indicates that theophany most often occurs via dreams. While the Genesis and Jubilees accounts say that "God spoke unto Noah", it is made clear in Enoch's earlier account that God communicates with Enoch through what he calls visions, which are akin to dream-like states.

Table 1

Methods of Theophany

\begin{tabular}{|l|l|l|}
\hline Text & Source & Detail \\
\hline Saisiyat & 1 & The old white-haired man came to him in a dream \\
\hline Gilgamesh & 197 & The gods told Prince Ea, who told Ut-napištim in a dream \\
\hline Jubilees & 5.21 & And He commanded Noah \\
\hline Genesis & 6.13 & And God said unto Noah \\
\hline Enoch & 83.3 & I saw in a vision \\
\hline
\end{tabular}

Note. Sources for Saisiyat are listed by paragraph (par.) from the Winkler's (2016) Taiwan Indigene; Sources for Ut-napištim are listed by line from Tablet 11 of the Epic of Gilgamesh; Sources for Jubilees are listed by chapter and verse; Sources for Genesis are listed by chapter and verse; Sources for Enoch are listed by chapter and verse.

The message that god conveys in each of the accounts is consistent. The chosen ones are explicitly given knowledge that a catastrophic flood is coming and that in order to survive it, they must make specific preparations.

Table 2

The Prophecy

\begin{tabular}{|l|l|l|}
\hline Text & Source & Detail \\
\hline Saisiyat & 1 & $\begin{array}{l}\text { The old man told him that a great storm would soon come to Oppehnaboon's } \\
\text { people. It would flood all of the land. }\end{array}$ \\
\hline Gilgamesh & 14 & The hearts of the great gods moved them to inflict the Flood. \\
\hline Jubilees & 5.21 & $\begin{array}{l}\text { And He commanded Noah to make him an ark that he might save himself from the } \\
\text { waters of the flood. }\end{array}$ \\
\hline Genesis & $\begin{array}{l}6.13 \\
\& \\
6.17\end{array}$ & $\begin{array}{l}\text { God said unto Noah, The end of all flesh is come before me; for the earth is filled } \\
\text { with violence through them; and, behold, I will destroy them with the earth. Even I, } \\
\text { do bring a flood of waters upon the earth, to destroy all flesh, wherein is the breath } \\
\text { of life, from under heaven; and everything that is in the earth shall die. }\end{array}$ \\
\hline Enoch & 106.15 & $\begin{array}{l}\text { There shall be a deluge and a great destruction for one year the waters of heaven } \\
\text { thrown down upon the earth. }\end{array}$ \\
\hline
\end{tabular}

Note. See note from Table 1.

Depending on one's interpretation of Genesis account, Noah has between 120 years and as little as 55 years to build and fill the ark. Ham and Hodge calculate that Noah has "a tentative range of about 55 to 75 years for a reasonable maximum time to build the ark" (170). After this, God shuts Noah's family inside the ark and for one hundred and fifty days and nights water floods the Earth.

While the Oppehnaboon and Ut-napištim accounts fail to provide specific amounts of time, it is clear that both of them are given enough time to build boats and otherwise prepare. In the case of Enoch, the prophecy is foretold immediately after the birth of Noah, six hundred years prior to the flood, and prophesied again multiple times to Noah.

Table 3

Timeline from Prophecy to Flood

\begin{tabular}{|l|l|l|}
\hline Text & Source & Detail \\
\hline Saisiyat & $1-2$ & Enough time to build boats \\
\hline Gilgamesh & 93 & Enough time to build boats \\
\hline Jubilee & 5.8 & 120 years \\
\hline Genesis & 6.3 & 120 years \\
\hline Enoch & 106 & 600 years (birth of Noah) \\
\hline
\end{tabular}

Note. See note from Table 1.

In the context of the deluge myth, the function of theophany is to warn the chosen one of an impending flood and to relate instructions about how to survive it. Oppehnaboon is further told that he "must persuade his people to build boats, otherwise they would be caught in the flood and would drown (par. 2)". Curiously, even though he successfully builds his boat on time, the god appears to Oppehnaboon a second time and tells him to 
abandon his boat and instead to lead his people to higher ground as none of them has built any boats. Oppehnaboon again obeys god's commandment, this time to no avail. Oppehnaboon and his sister alone are saved by a providential floating loom. Among Formosan flood myths, the motif of surviving the deluge on a loom is largely limited to the Saisiyat. However, "in the Sediq myth the flood waters were only satisfied when the people offered a young woman with a weaving shuttle (loom) and a young man placed in a carrying basket" (Covell 46).

Table 4

The Message from God

\begin{tabular}{|l|l|l|}
\hline Text & Source & Detail \\
\hline Saisiyat & 2 & Oppehnaboon must persuade his people to build boats. \\
\hline Gilgamesh & 23 & Tear down the house and build a boat! \\
\hline Jubilees & 5.21 & He commanded Noah to make him an ark \\
\hline Genesis & 6.14 & Make thee an ark of gopher wood \\
\hline Enoch & 67.2 & And now the angels are making a wooden boat \\
\hline
\end{tabular}

Note. See note from Table 1.

Ut-napištim and Noah are commanded to load their boats with their families and animals of every kind. Oppehnaboon in contrast is told to focus his efforts on saving his people. However, of the twenty two Saisiyat flood myths that this researcher has collected, only one makes any mention of animals (Z. Feng). Moreover, while the majority of other Taiwanese Austronesian myths of the flood include animals who seek a haven on the top of a mountain, only one Truku myth specifically mentions animals (birds) being placed in boats with the survivors (Tian "Truku” 59-60).

Table 5

Cargo Manifest Order

\begin{tabular}{|l|l|l|}
\hline Text & Source & Detail \\
\hline Saisiyat & $\begin{array}{l}2 \& \\
5\end{array}$ & $\begin{array}{l}1^{\text {st }} \text {. All of the people in boats } \\
2^{\text {nd }} \text {. lead all of his people to the land above the flood waters }\end{array}$ \\
\hline Gilgamesh & 26 & Make [the seed of] all living beings go up into the boat. \\
\hline Jubilees & 5.20 & Beasts, cattle, and birds, and every moving thing. \\
\hline Genesis & 7.16 & $\begin{array}{l}\text { And they that went in, went in male and female of all flesh, as God had commanded } \\
\text { him and the LORD shut him in }\end{array}$ \\
\hline Enoch & 67.2 & The seed of life \\
\hline
\end{tabular}

Note. See note from Table 1.

All three chosen ones respond to god's command with unreserved obedience. Oppehnaboon, Noah and Utnapištim all warn their fellow man and build boats. These acts further illustrate why these particular men are selected to be survivors.

Table 6

Response to Prophecy

\begin{tabular}{|l|l|l|}
\hline Text & Source & Detail \\
\hline Saisiyat & 3 & Oppehnaboon went ahead and built his own boat. \\
\hline Gilgamesh & 33 & $\begin{array}{l}\text { 'My lord, thus is the command which you have uttered } \\
\text { I will heed and will do it. }\end{array}$ \\
\hline Jubilees & 5.22 & Noah made the ark in all respects as He commanded him \\
\hline Genesis & 7.5 & Noah did according unto all that the Lord commanded him. \\
\hline Enoch & 67 & Noah did according unto all that the Lord commanded him. \\
\hline
\end{tabular}

Note. See note from Table 1.

All five accounts are conclusive about the Earth being utterly overwhelmed with water. The Saisiyat account mentions strong wind. Often, heavy rain in Taiwan is accompanied by gale force winds during typhoons. This is the type of detail that could have been added to the myth in order to remind the listener of weather events associated with the typhoons which people in Taiwan are highly familiar. Furthermore, the Epic of Gilgamesh (130) states that wind "flattened the land". 
Table 7

Manifestation of the Global Deluge

\begin{tabular}{|l|l|l|}
\hline Text & Source & Detail \\
\hline Saisiyat & 4 & $\begin{array}{l}\text { Torrents of rain poured down from the heavens and the winds blew with a ferocity } \\
\text { such as they had never seen. }\end{array}$ \\
\hline Gilgamesh & 108 & $\begin{array}{l}\text { The Flood came, overwhelming the people like an attack. Even the gods were } \\
\text { frightened by the Flood, and retreated }\end{array}$ \\
\hline Jubilees & 5.24 & $\begin{array}{l}\text { The Lord opened seven flood-gates of heaven, And the mouths of the fountains of } \\
\text { the great deep }\end{array}$ \\
\hline Genesis & 7.11 & $\begin{array}{l}\text { All the fountains of the great deep broken up, and the windows of heaven were } \\
\text { opened. }\end{array}$ \\
\hline Enoch & \multicolumn{2}{|l|}{ Unstated } \\
\hline
\end{tabular}

Note. See note from Table 1.

Typically, unless a number is central to a mythic plot, it may change over time or be omitted all together. Interviews with the Tao on Orchid Island revealed that, for the Tao, time was counted in "generations" (De Beauclair "Jar Burial" 168). When Tao elders were asked about the practice of jar burials, they were able to state when the practice ended by counting generations. Nevertheless, day and year counts are included in many Formosan flood myths including those of the Tao.

Table 8

Duration of Rain \& Time Floating

\begin{tabular}{|l|l|l|l|}
\hline & Source & Duration of Rain & Time Floating \\
\hline Saisiyat & & Unstated & $\begin{array}{l}\text { Unknown. However, being without provision they } \\
\text { neither starved nor thirsted to death. }\end{array}$ \\
\hline Gilgamesh & 129 & Seven days & Unstated \\
\hline Jubilees & 5.27 & Five months or 150 days & 1 year \\
\hline Genesis & 7.24 & 150 days & 370 days (1 year) \\
\hline Enoch & 78 & 150 days & 1 year \\
\hline
\end{tabular}

Note. See note from Table 1. See Ham and Hodge for Genesis calculation.

The accounts of Noah specify that the waters raise fifteen cubits above all the high mountains. A cubit is a form of measurement based on the distance from the elbow to the fingertips. Most researchers believe that a cubit was approximately 20 inches long or $50.8 \mathrm{~cm}$ (Ham and Hodge 194). Based on this approximation, fifteen cubits is about 7.62 meters. For comparison, the ark is three hundred cubits long, fifty cubits wide and thirty cubits tall (Gen. 6.15) indicating that the depth of the water is only half the height of the ark.

All of the myths concur that after the rains stops, "the terrain was as flat as a roof" (Gilgamesh, 133) because "the waters prevailed exceedingly upon the earth; and all the high hills, that were under the whole heaven, were covered" (Gen. 7.19). That is, the deluges described are not merely local natural disasters.

Table 9

Depth / Expanse of Water

\begin{tabular}{|l|l|l|}
\hline Text & Source & Detail \\
\hline Saisiyat & 10 & $\begin{array}{l}\text { Looking all around there was nothing but water. The entire world was flooded except } \\
\text { for the piece of land on which they were standing. }\end{array}$ \\
\hline Gilgamesh & $\begin{array}{l}133-135 \\
\& \\
139-140\end{array}$ & $\begin{array}{l}\text { And all the human beings had turned to clay! } \\
\text { The terrain was as flat as a roof. } \\
\text { I looked around for coastlines in the expanse of the sea, } \\
\text { And at twelve leagues there emerged a region of land. }\end{array}$ \\
\hline Jubilees & 5.26 & 15 cubits did the waters rise above all the high mountains \\
\hline Genesis & 7.20 & 15 cubits upward did the waters prevail; and the mountains were covered. \\
\hline Enoch & & Unstated \\
\hline
\end{tabular}

Note. See note from Table 1 .

Noah survives with his wife and their three sons and daughters in law. Ut-napištim and his wife survive with an untold number of workmen, family members and others who join them on the boat. Uniquely Oppehnaboon survives with only his sister. This bleak circumstance provides the necessary impetus for god's commandment that Oppehnaboon to marry his sister. "Marry his own sister? How could he do that? It was against the rules! What should Oppehnaboon do? Violate the rules or go against the advice of the old whitehaired man? The old man had been right before. He is probably right this time too" (Winkler, 2016, p. 27)! 
Table 10

Deluge Survivors

\begin{tabular}{|l|l|l|}
\hline Text & Source & Detail \\
\hline Saisiyat & 10 & Oppehnaboon and his sister (2 people) \\
\hline Gilgamesh & $83-85$ & Ut-napištim and his wife, kith and kin, and craftsmen (many people) \\
\hline Jubilees & 6.10 & Noah and his sons (4 men) \\
\hline Genesis & 8.16 & Thou, and thy wife, and thy sons, and thy sons' wives with thee. (8 people) \\
\hline Enoch & & Unstated \\
\hline
\end{tabular}

Note. See note from Table 1.

Noah and Ut-napištim survive in giant boats which were filled with every kind of animal on earth. However, Oppehnaboon survives the inundation by floating on a wooden loom. The Oppehnaboon myth focuses on the death and resurrection of people and neglects to mention animals.

Table 11

The Animals

\begin{tabular}{|l|l|l|}
\hline Text & Source & Detail \\
\hline Saisiyat & & Unstated \\
\hline Gilgamesh & 86 & All the beasts and animals of the field \\
\hline Jubilees & 5.32 & Beasts, cattle, and birds, and every moving thing. \\
\hline Genesis & $7.8-9$ & $\begin{array}{l}\text { Of clean beasts, and of beasts that are not clean, and of fowls, and of everything that } \\
\text { creepeth upon the earth. There went in two and two unto Noah into the ark, the male } \\
\text { and the female, as God had commanded Noah. }\end{array}$ \\
\hline Enoch & & Unstated \\
\hline
\end{tabular}

Note. See note from Table 1.

God gives Noah very specific dimensions for the ark. Likewise, Ut-napištim's workmen build a seven level deep cube-like structure at the behest of Prince Ea. However, the boat commissioned by the old man with white hair in the Saisiyat account is not built according to divine specifications. Oophenaboon simply builds a boat which makes sense in preliterate Taiwan.

The existence of ancient ships like the Greek war ship Leontifera which carried at least 2,800 men in 280 BC and Ptolemy Philopator ship which carried over 4,400 men in the late third century BC validate the possibility that a ship the size of Noah's could have actually been built in antiquity and a number of researchers believe that such a craft could have been built (Ham and Hodge 198).

Table 12

Boat Dimensions

\begin{tabular}{|l|l|l|}
\hline Text & Source & Detail \\
\hline Saisiyat & & Unstated \\
\hline Gilgamesh & $56-60$ & $\begin{array}{l}\text { The boat which you are to build, its dimensions must measure equal to each other its } \\
\text { length must correspond to its width. 10 times 12 cubits each }\end{array}$ \\
\hline Jubilees & 5.22 & And Noah made the ark in all respects as He commanded him \\
\hline Genesis & $6.15-16$ & $\begin{array}{l}\text { The length of the ark shall be three hundred cubits, the breadth of it fifty cubits, and } \\
\text { the height of it thirty cubits. } \\
\text { 16 A window shalt thou make to the ark, and in a cubit shalt thou finish it above; and } \\
\text { the door of the ark shalt thou set in the side thereof; with lower, second, and third } \\
\text { stories shalt thou make it. }\end{array}$ \\
\hline Enoch & & Unstated \\
\hline
\end{tabular}

Note. See note from Table 1.

In the immediate aftermath of the flood, the gods regret having brought such total destruction upon the Earth. Specifically, the gods regret the global death toll which some scholars estimate to have been in the range of five to seventeen billion people (Pickett). The Oppehnaboon myth reveals that "all the people of their tribe were gone and only they were left behind" (par. 10).

The old man with white hair remembers Oppehnaboon. Appearing to Oppehnaboon a third time, god says "Now there are only you and your sister" (par. 11)! God makes a new covenant with Noah saying "Never again shall all flesh be cut off by the waters of the flood; never again shall there be a flood to destroy the earth" (Gen. 9.11). As a symbol of this promise, God says "I set My rainbow in the cloud, and it shall be for the sign of the covenant between Me and the earth...I will remember My covenant which is between Me and you and every living creature of all flesh; the waters shall never again become a flood to destroy all flesh" (Gen. 9.13-15).

Ut-napištim tells Gilgamesh that the gods are highly distraught with the aftermath of their decision to destroy the Earth. Their regret is so strong that they refer to their own words ordering the flood as "evil thing." Even stronger self-doubt is expressed by the gods as they relent that "No sooner have I given birth to my dear 
people than they fill the sea like so many fish" (Gilgamesh, 123).

Table 13

God Repents and the New Covenant

\begin{tabular}{|l|l|l|}
\hline Text & Source & Detail \\
\hline Saisiyat & 11 & Now there are only you and your sister. \\
\hline Gilgamesh & $120-123$ & $\begin{array}{l}\text { How could I say evil things in the Assembly of the Gods, ordering a catastrophe to } \\
\text { destroy my people? No sooner have I given birth to my dear people than they fill the } \\
\text { sea like so many fish!' }\end{array}$ \\
\hline Jubilees & $6.15-16$ & $\begin{array}{l}\text { He gave to Noah and his sons a sign that there should not again be a flood on the } \\
\text { earth. He set His bow in the cloud for a sign of the eternal covenant that there should } \\
\text { not again be a flood on the earth to destroy it all the days of the earth. }\end{array}$ \\
\hline Genesis & 9.15 & $\begin{array}{l}\text { I will remember My covenant which is between Me and you and every living } \\
\text { creature of all flesh; the waters shall never again become a flood to destroy all flesh. }\end{array}$ \\
\hline Enoch & 55.2 & $\begin{array}{l}\text { And he swore by His Great Name "From now on I will not act like this towards all } \\
\text { those who dwell upon the dry ground. And I will put a sign in Heaven, and it will be } \\
\text { a pledge of faith between me and them forever, so long as Heaven is above the } \\
\text { Earth. }\end{array}$ \\
\hline
\end{tabular}

Note. See note from Table 1.

Both Noah and Ut-napištim employed birds to assess the status of the receding flood waters. However, as Oppehnaboon survived the flood on a floating loom and had no birds or animals at his disposal, he was unable to send birds aloft like Noah and Ut-napištim.

Table 14

The Birds

\begin{tabular}{|l|l|l|}
\hline Text & Source & Detail \\
\hline Saisiyat & & Unstated \\
\hline Gilgamesh & 147 & Dove \\
& 150 & Swallow \\
& 153 & Raven \\
\hline Jubilees & & Unstated \\
\hline Genesis & 8.7 & Raven \\
& 8.8 & Dove \\
& 8.9 & Dove \\
\hline Enoch & & Unstated \\
\hline
\end{tabular}

Note. See note for Table 1. Locations in the text are placed next to the birds they describe.

After the flood, the chosen ones come to rest on mountain tops. As is typically found among flood accounts, the mountain upon which the chosen one came to rest is one geographically near the location where the story is told. This is a logical place for survivors to go for a couple of reasons. First, in order to make the account easier for listeners to understand and relate to, it is important for the story to be linked to a location that falls within the jurisdiction of the tribe. Also, like most global flood accounts, the accounts of Ut-napištim, Noah and Oppehnaboon imply that before the inundation, the earth was topographically disparate from its configuration afterwards. In essence, the flood and earthquakes that occurred created the mountains which emerged from the otherwise flat antediluvian plain. The account of Ut-napištim states that "The terrain was as flat as a roof" (Gilgamesh 133). Jubilees tells us that "all the mouths of the abysses of the earth were opened, and the water began to descend into the deep" (5.27). Geneses likewise records that "all the fountains of the great deep broke up" (Gen. 7.11). The account of Oppehnaboon new mountains came forth from the water. The Saisiyat myth also supports Thomas Burnet's insightful theory that "the face of the Earth before the Deluge was smooth, regular and uniform; without Mountains, and without a Sea" (Burnet 53).

The Saisiyat deluge myth states that the survivors landed on Dabajian Mountain in Hsinchu County, Taiwan. This is corroborated by other Saisiyat flood myths in the Formosan Deluge Mythography as well as non-deluge origin myths of the Saisiyat which record Dabajian as the place where their ancestors were born. Standing 3,492 meters tall Dabajian Mountain is one of the tallest mountains in Taiwan and is known as Papak Waka to the Saisiyat meaning "ear-shaped rock" (Pu, 2012, p. 32). 
Table 15

Resting Place of the Boat

\begin{tabular}{|l|l|l|}
\hline Text & Source & Detail \\
\hline Saisiyat & 9 & Dabajian Mountain (大霸尖山 / Mount Sylvana) \\
\hline Gilgamesh & 141 & Mount Nimuš \\
\hline Jubilees & 5.28 & Mount Lûbâr, one of the mountains of Ararat \\
\hline Genesis & 8.4 & The mountains of Ararat \\
\hline Enoch & & Unstated \\
\hline
\end{tabular}

Note. See note from Table 1.

All three of the chosen ones are remembered by the gods. Upon the discovery that Ut-napištim has survived the deluge, Enlil enters Ut-napištim's boat, takes Ut-napištim by the hand and touching Ut-napištim and his wife's foreheads says "Previously Ut-napištim was a human being. But now let Ut-napištim and his wife become like us, the gods! Let Ut-napištim reside far away, at the Mouth of the Rivers" (Gilgamesh 202). In doing so, both Ut-napištim and his wife join the Assembly of the Gods and thus are alive hundreds of years after the flood to tell Gilgamesh this story.

"And God blessed Noah and his sons" (Gen. 9.1). Noah is given a mandate to repopulate the Earth, dominion over all animal life, a promise of no more global floods and the right to eat meat which had previously been forbidden.

The second half of Genesis 9 implies that Noah lives out his centuries after the flood drinking wine. But Jubilees provides a more positive account stating 'Noah began to enjoin upon his sons' sons the ordinances and commandments, and all the judgments that he knew, and he exhorted his sons to observe righteousness, and to cover the shame of their flesh, and to bless their Creator, and honor father and mother, and love their neighbor, and guard their souls from fornication and uncleanness and all iniquity. For owing to these three things came the flood upon the earth, namely, owing to the fornication wherein the Watchers against the law of their ordinances went a-whoring after the daughters of men, and took themselves wives of all which they chose and they made the beginning of uncleanness" (Jubilees. 7.22).

Jubilees also states that Noah's grandchildren fear him "And he (Noah's grandson Kainam) found a writing which former generations had carved on the rock, and he read what was thereon, and he transcribed it and sinned owing to it; for it contained the teaching of the Watchers in accordance with which they used to observe the omens of the sun and moon and stars in all the signs of heaven. And he wrote it down and said nothing regarding it; for he was afraid to speak to Noah about it lest he should be angry with him on account of it" (Jubilees. 8.3-4). Kainam's fear of keeping secrets from Noah reflects his patriarchal and judicial role in his later years.

Oppehnaboon is given authority from god to take Mayanaboon as a wife, dismember his own children and name the new people that spring forth from the corpse. "All of the children now had names. If they forgot their name Oppehnaboon would teach them again" (Winkler 30). The inclusion of the point that Oppehnaboon must remind his children what their names were signifies Oppehnaboon's superiority and his status as the keeper of knowledge. This detail of the chosen one having superior wisdom is also implied in the accounts of Noah and Ut-napištim.

The Saisiyat myth says that Oppehnaboon serves as the keeper of knowledge after the flood. The narrative further expounds that "They chopped the little child into many pieces and threw these into the water. Each one of the little pieces immediately became a person" (Winkler 29)! This represents Oppehnaboon's ability to perform magic, an important element featured throughout Formosan mythology. The Saisiyat's Lightning Woman uses magic to improve crop yields. The Saisiyat's Pas-Taai myth of the Negritos also records the wielding of benevolent magic. Clearly, since normal people cannot dismember each other in order to create new people, Oppehnaboon possesses special magic abilities which are not bestowed upon others. The dismemberment-intolife motif is likewise found in the Mayan myth of Itzam Kab Ahiin as well as the Nahuatl account of Tezcatlipoco and Quetzalcoatl who chop up the Tlaltecuhtli monster in order to create the world (Garcia 8). 
Table 16

Postdiluvian Order from God

\begin{tabular}{|l|l|}
\hline Source & Detail \\
\hline $\begin{array}{l}\text { Saisiyat } 11 \\
13\end{array}$ & $\begin{array}{l}\text { In order for your tribe to survive you must marry and have children! } \\
\text { They chopped the little child into many pieces and threw these into the water. Each one of the } \\
\text { little pieces immediately became a person! } \\
\text { The names that oopehnaboon gave the children are the original names of the ancestors of the } \\
\text { Saisiyat. } \\
\text { If they forgot their name Oppehnaboon would teach them again. }\end{array}$ \\
\hline Gilgamesh 203 & \multicolumn{1}{|l|}{ Now let Ut-napištim and his wife become like us, the gods! } \\
\hline 15 & $\begin{array}{l}\text { Bubilees } 6.5-\text { Whoso sheddeth man's blood by man shall his blood be shed } \\
\text { And He gave to Noah and his sons a sign that there should not again be a flood on the earth. }\end{array}$ \\
\hline $\begin{array}{l}\text { Genesis } \\
8.16-17\end{array}$ & $\begin{array}{l}\text { Bring forth with thee every living thing that is with thee } \\
\text { be fruitful, and multiply upon the earth } \\
\text { neither will I again smite any more everything living, as I have done. While the earth } \\
\text { remaineth, seedtime and harvest, and cold and heat, and summer and winter, and day and night } \\
\text { shall not cease. } \\
\text { And the fear of you and the dread of you shall be upon every beast } \\
\text { Every moving thing that liveth shall be meat for you; even as the green herb have I given you } \\
\text { all things. }\end{array}$ \\
\hline 9.22 &
\end{tabular}

Note. See note from Table 1.

\section{Conclusion}

Comparative analysis of the flood texts reveals a plethora of significant correlations between the Saisiyat account of Oppehnaboon and other major global flood myths. Varying parallels in methods of theophany, prophecies, timelines from prophecies to flood, the messages from the gods, boat cargo manifests, responses to the prophecies, manifestations of the deluge, depths and expanses of water, deluge survivor profiles, resting places of the boats (or loom), postdiluvian divine orders, the gods' repentance and the new covenant were documented. This study also establishes that unlike the accounts of Noah and Ut-napištim, the Oopehnaboon account is deficient in details related to animals, boat dimensions, duration of time floating or the duration of rain among others.

The preponderance of connections among the flood myths is significant. The Saisiyat flood myth is more like, rather than unlike, its western counterparts which were written thousands of years ago on different continents. Out of the seventeen points of reference described in the tables, only five topics were neglected by the Saisiyat. These results could be interpreted in one of two ways.

The first possible conclusion is what I refer to as the people are people argument which essentially relies on the premise that myths are universal because human nature is universal. Human propensity to smile when happy, cry when sad, fight when angry and protect loved ones, illustrates this argument and thus infers that the construction of myths must also be universal. Moreover, since there is no region on earth that does not experience flooding at certain intervals, it stands to reason that all cultures should have stories about floods which destroyed their homes and forced them to evacuate.

The main criticism of the people are people argument is that flooding is not the only universal weather event which negatively impacts people around the world. Instead, flooding is just one of a plethora of natural disasters which can and do occur. Hurricanes and tropical storms, landslides and debris flows, thunderstorms and lighting, tornadoes, wildfire, winter and ice storms, sinkholes, drought, hail, impact events and earthquakes are just some of the other universal weather events which are found around the globe. However, myths about these types of natural disasters pale in comparison by volume and universality with those of the great flood. The absence of universally recognized sinkhole or thunderstorm myths illustrates the flaw in the people are people theory.

The second possible conclusion that may be reached is that these myths all describe an actual flood or floods which actually occurred. Everything that the antediluvian cultures created, including literacy may have actually been lost to the flood waters as the oral traditions insist. Perhaps the Amis and Bunun myth which states that the stone tablets on which the people had written their languages were lost in the waters of the flood $(C$. Feng 71 and 223) are based on the same lost tablets that Kainam finds in Jubilees chapter 8.

The conviction that "there is only the most superficial connection between most flood stories" (Longman and Walton 164) is a commonly held erroneous view in part because there are so few readily available global flood myth corpora. Studies such as that of Longman and Walton compare Biblical records with other ancient 
near east texts consider that including the disclaimer "methodologically, we have noted that events are not authoritative" strong enough to support their uninformed theories (Longman and Walton 177).

This study reveals that the Formosan Saisiyat flood myth which describes visions of a white haired god who tells one specially chosen man to build a boat in order to save himself from an impending deluge that actually happens and actually kills everyone who isn't in a boat is remarkably similar to the Noachian account. The fact that the Saisiyat survivor then makes landfall on the tallest mountain where the god reappears and repentantly instructs the them again proves a more than "superficial connection".

In 1914, Mori Ushinosuke wrote that "the people's legends are artworks worthy of their pride and their only history. A glimpse into their unique ethnic mentality, these myths are valuable sources for a better understanding of their ethnic origins" (Ushinosuke 249). Research into Formosan mythology must take into account the existence of other global myths that exhibit parallel structures and features. Understanding how Formosan myths are related to those of other indigenous peoples' oral traditions around the globe may help us better gain a more complete understanding of who we are as human beings, our cultural origins and our shared history.

Unfortunately, over a century after Mori Ushinosuke's insights, the scattered and fragmented corpus of Formosan mythology has been preserved primarily in Japanese and Mandarin, languages largely restricted to readers in Japan, China, Taiwan and Singapore. Additionally, seventy years after Del Rey's call for further Formosan text collection "in order to determine the interdependence of Formosan native folklore and its eventual transoceanic origins and parallels" (Del Rey 72-72) very limited corpora are available in the global lingua franca and the texts which are available require a dedicated researcher much time and effort to locate and procure. The nearly six hundred texts regarding creation myths and other legends in Sayama and Onishi's (1923) A Collection of the Legends of the Formosan Aborigines remain un-translated into English as a single collection. The two hundred and eighty-four texts recorded in Asai and Ogawa's (1935) Traditions and Myths of the Taiwan Aborigines persist to be unavailable in English translation with the three notable exceptions. The first out of print and exceptionally rare R. F. Baudhuin's Selected Readings totally excludes all of the recorded myths and instead focuses on taboo and customs. However, the only way to determine this is to purchase a copy and see for one's self because it is so rarely cited. The next exception is Early and Whitehorn's One Hundred Paiwan Texts which exclusively focuses on the Paiwan tribe and contains seventy-four translations of Asai and Ogawa's work with just two versions of the flood myth. One Hundred Paiwan Texts is the most comprehensive volume of English language Paiwan mythic texts ever published but it is expensive at \$300 USD per copy. The third exception is Ting-Jui Ho's 1967 Comparative Study of Myths and Legends of Formosan Aborigines which contains ninetythree Formosan texts sourced from Sayama and Onishi as well as Asai and Ogawa, eight of which relate to the deluge.

The single richest source of Formosan flood texts is Chungchen Pu's Literary History of Taiwanese Indigenous Peoples which includes sixty-two deluge myths alongside hundreds of myths related to the creation of the world, the origin of man, visitors from the sky, shooting the sun, the golden age, migrations, the kingdom of women, gods and spirits, giants, magical negritos, cannibals, witchcraft, human-animal chimeras, monsters, bestiality, giant and toothy genitalia and much more. However, Pu's book is not available on most (if any) English book selling web stores and since the title lacks keywords "Formosan", "Aboriginal, "myth" or "legend", it is nearly impossible for international English readers to discover based on key word search results.

The Formosan Deluge Mythography currently being compiled and analyzed by the author will simplify and facilitate access to hundreds of Formosan deluge myths. The cultures, origins, religions and histories of the impressive and ancient Formosan language speaking tribes merit deeper investigation and consideration. However, absent the establishment of an English language corpus of Formosan myths their existence will continue to evade wide spread recognition and face the prospect of being relegated to obscurity.

\section{References}

Bascom, William. "The Forms of Folklore: Prose Narrative." Journal of American Folklore, Vol. 78, 1965,No. 307, pp. 3-20.

Baudhuin, Robert. Selected Readings Translated from Traditions and Myths of the Taiwan Aborigines Complied by Ogawa and Asai C. 1930. 1960.

Burnet, Thomas. The Sacred Theory of the Earth. R. Norton, 1691, London.

Carney, Scott. "Did a Comet Cause the Great Flood?" Discover Magazine, November 15, 2007. Retrieved July 22, 2020 from https://www.sott.net/article/144125-Did-a-Comet-Cause-the-Great-Flood

Cauquelin, Josiane. The Aborigines of Taiwan. The Puyuma: from headhunting to the modern world. Rutledge, 2004, New York, USA.

Chen, Jian-Xian and Ying-Yi Cao. Studying on the Rebirth-type Flood Myth of the Indigenous People in Taiwan. Vol. 2, 2009, p. 289-307 doi:10.29455/MJWSNK.200902.0016

Covell, Ralph. Pentecost of the Hills in Taiwan The Christian Faith among the Original Inhabitants. Hope Publishing House, 1998, Pasadena, California, USA. 
De Beauclair, Inez. "Jar Burial on Botel Tobago Island". Asian Perspectives. 15 (2): 1972. p. 167-176.

De Beauclair, Inez. Neglected Formosa: A Translation from the Dutch of Frederick Coyett's Verwaerloosde Formosa. Chinese Materials and Research Aids Service Center, Occasional Series 21, 1975, San Francisco.

Del Re, Arundel. Creation Myths of the Formosan Natives. The Hokuseido Press. 1951,Tokyo, Japan.

Fackrell, Almon. Jesus Christ Visited Ancient America. Dorrance Publishing Co., Inc., 2013, Pittsburgh, Pennsylvania.

Feng, Chien-chang. Experiencing the State: The Making of Falangaw Amis Community in Taiwan. 2015, Doctoral dissertation, University of Toronto, Canada.

Feng, Zhengjun. "The Corpse." Saisiyat Oral Traditions, 1995, Retrieved November 1, 2020 from http://9years.mlc.edu.tw/9yearsFiles/9years/3601/html1.html

Fernandez, Pablo. One Hundred Years of Dominican Apostolate in Formosa 1859-1958. SMC Publishing Inc., 1994, Taipei, Republic of China.

Garcia, Erik. "The Maya Flood Myth and Decapitation of the Cosmic Caiman." The PARI Journal, Vol. 7, 2006, p. 1-10. Retrieved July 15, 2020 from http://www.mesoweb.com/pari/publications/journal/701/Flood_e.pdf

Gish, Duane, Gloria Clanin, Earl Snellenberger and Bonita Snellenberger. Dinosaurs by Design. Green Forest, AR: Master Books, 1992.

Groeneveld, Emma. "Ice Age.” World History Encyclopedia, May 24, 2017, Retrieved July, 18, 2021 from https://www.worldhistory.org/Ice_Age/.

Ham, Ken and Bodie Hodge. A Flood of Evidence 40 Reasons Noah and the Ark Still Matter. Master Books, 2018

Hoena, Blake. Cleansing the World. Flood Myths Around the World. Capstone Press, 2018, North Mankato, Minnesota.

Isaak, Mark. "Flood Stories From Around the World." Talk Origins, 2002, Retrieved August 20, 2020 from http://www.talkorigins.org/faqs/flood-myths.htm

Longman III, Tremper and John Walton. The Lost World of the Flood. IVP Academic, 2018.

MacKay, George. From Far Formosa The Island, its People and Missions. Flemming H. Revell Company, New York, 1885.

Morris, John. "Why Does Nearly Every Culture Have a Tradition of a Global Flood?" Institute for Creation Research, September 1, 2001, Retrieved July 4, 2020 from https://www.icr.org/article/why-does-nearlyevery-culture-have-tradition-globa

Official Journal of the National Geographic Society. Vol. 233, April 2018, No. 4.

Puyuma - "A Store of Myths." Ministry of Culture. Retrieved December 10, 2020, from https://ticeda.moc.gov.tw/home/en-us/PuyumaShenhua

Pickett, Tom. Population of the Pre-Flood World. Lambert Dolphin's Library. 2004. Retrieved January 1, 2020 from http://www.ldolphin.org/pickett.html

$\mathrm{Pu}$, Zhongchen. Literary History of Taiwanese Indigenous Peoples (Volume I). Le Jin Books Ltd., 2012, Taipei, Republic of China.

Russell, Terrance. "Traditional Culture and Contemporary Performance: Adaw Palaf's The Great Flood." Journal of Modern Literature in Chinese. Issue 1, Vol. 10, Summer 2010.

Schoch, Robert. Voyages of the Pyramid Builders. Penguin, 2003, New York.

Tian, Zheyi. Puyuma Myths and Legends. Morning Star Press, 2003.

Tian, Zhiye. Myths and Legends of the Truku. Morning Star Press. 2020.

The Bible. The King James Version. Retrieved from https://www.kingjamesbibleonline.org/

The Book of Enoch. Translated by R.H. Charles, 1917. Retrieved from https://www.sacred-texts.com/bib/boe/

The Book of Jasher. J.H. Parry \& Company, 1887. Retrieved from https://www.sacredtexts.com/chr/apo/jasher/index.htm

The Book of Jubilees. Translated by R.H. Charles, Society for Promoting Christians Knowledge, London, 1917. Retrieved from https://www.sacred-texts.com/bib/jub/index.htm

The Epic of Gilgamesh. Translated by R. Campbell Thompson, 1928. Retrieved from https://www.sacredtexts.com/ane/eog/index.htm

"Theophany" (a manifestation of God or a deity). Mirriam-Webster's New World College Dictionary ( $4^{\text {th }}$ ed.). 2008, p. 1484.

Tsai, Cheng-Hsiu, Ewan Fordyce, Chun-Hsiang Chang and Liang-Kong Lin. "A Review and Status of Fossil Cetacean Research in Taiwan.” Taiwan Journal of Biodiversity, Vol. 15 (2), 2013, p. 113-124.

Tseng, Chien-tsi. "The Great Flood." Taiwan Literature English Translation Series. Forum for the Study of World Literatures in Chinese. University of California Santa Barbara, No. 24. January, 2009, p. 17

Tseng, Chien-tsi. Zuling de jiaobu - Beinan zu shisheng zhixi kouchuan shiliao (Footsteps of the Ancestral Sprits: Orally Transmitted Historical Records of the Shisheng ranch of the Puyuma Tribe). Chenxing Chubanshe, 1998, Taichung, Republic of China. 
Tsuchida, Shigeru. "Preliminary Reports on Saisiyat: Phonology." Gengo Kenkyu, Vol. 46, 1964, pp. 42 - 52. Ushinosuke, Mori. Taiwanese Banzin. Special Taiwanese Custom and Practice Research Board. 1914.

Wilkinson, Philip. The Mythology Book. DK Penguin Random House, 2018.

Winkler, Robin. Taiwan Indigene: Meaning Through Stories. Third Nature. Vol. 9, 2016, Republic of China.

Zhong, Zhi-cheng. "The Forgotten Creation Myths of Taiwan." Indigenous Sight, October 23, 2018, Republic of China, Retrieved July 20, 2020 from https://insight.ipcf.org.tw/en-US/article/28 